
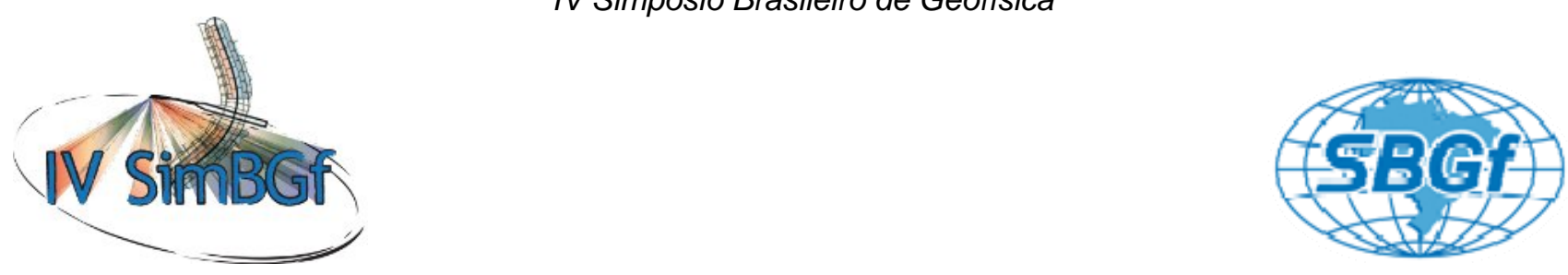

\title{
Space-time Analysis of Water Injection in the Vadose Zone
}

Téo Paiva dos Reis, Anderson Alvarenga de Moura Meneses and Jandyr M. Travassos

Observatório Nacional, Coordenação de Geofísica

Copyright 2010, SBGf - Sociedade Brasileira de Geofísica

Este texto foi preparado para a apresentação no IV Simpósio Brasileiro de Geofísica, Brasília, 14 a 17 de novembro de 2010. Seu conteúdo foi revisado pelo Comitê Técnico do IV SimBGf, mas não necessariamente representa a opinião da SBGf ou de seus associados. É proibida a reprodução total ou parcial deste material para propósitos comerciais sem prévia autorização da SBGf.

\begin{abstract}
Preliminary results of subsurface infiltration controlled experiment monitored by GPR are presented. We present the GPR profiles and processing method that allows the identification of temporal change patterns in the subsurface saturation.
\end{abstract}

\section{Resumo}

Resultados preliminares de experimento controlado de infiltração de subsuperfície monitorada através de método GPR são apresentados. Apresentamos os perfis GPR obtidos e método de processamento que permite a identificação de padrões de modificações temporais na saturação da subsuperfície.

\section{Introduction}

The problem of fluid infiltration in porous media is extremly important in several areas. In particular, water infiltration and subsurface saturation are among the subjects studied in environmental sciences. Ground Penetrating Radar (Davis e Annan, 1989) and the analyses derived from this technique are important allies of the data acquisition, as well as theoretical and practical developments in Geophysics. For example, Huisman et al. (2003) review techniques for measurement of water content in subsurface. Although the studies aforementioned and other studies (e.g., Galagedara et al., 2005) describe quantitatively the problem of the water content, with respect to their time variation, it is not common to find works concerned to the visualization of the process dynamics.

Thus, in this report we present preliminary results concerning GPR profiles analyses obtained in a controlled experiment related to water infiltration in a subsurface, aiming to study the dynamics of this process and, in particular, its visualization.

In summary, we intend to present: (i) unpublished GPR profiles (radargrams), obtained in controlled experimenf of water injection in subsurface; and (ii) an approach for the process visualization for future development and future applications of the GPR technique applied to water injection studies.

\section{Data Acquisition}

The test site is a recent sedimentation area of of $8 \mathrm{~m} \times 8$ $\mathrm{m}$ located on the Santa Catarina state, at Southern Brazil. That test site was chosen on the basis of a previous GPR/VES survey, which covered an area of $35000 \mathrm{~m}^{2}$.

Water was injected in the center of the test site just after the background measurements, as shown in Figure 1. We have taken water from a nearby drainage pit in order to assure that we didn't modify the geochemistry characteristics of that media, pumped to a $1000 \ell$ reservoir.

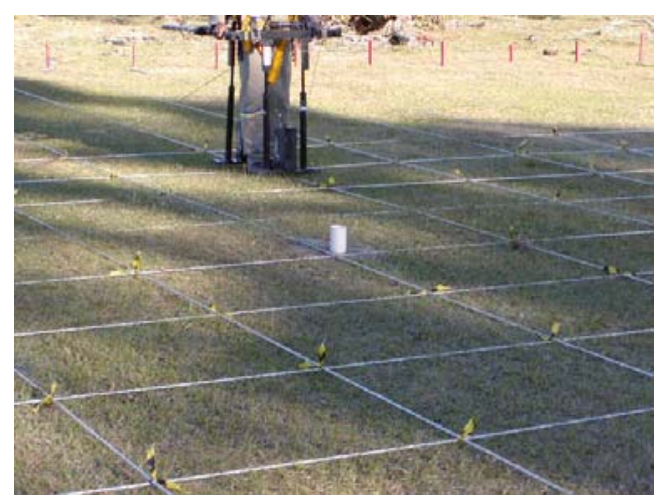

Figure 1 - The test site: $8 m \times 8 m$ area in Santa Catarina, Brazil.

Water injection of $501 \ell$ was done in one stage after the background survey, in February, 2005, within a time period of 10 hours and 54 minutes, in a total of 18 surveys, originating 18 sections. We concentrated in just the N-S direction, having the injection point halfway its length.

Data were obtained in fixed-offset surveys, collected with a Pulse Ekko $200 \mathrm{MHz}, 32$ stack, 250 ns time window and 400 ps sample frequency. Trace spacing was $0.05 \mathrm{~m}$, later decimated to $0.1 \mathrm{~m}$. Broadside parallel polarization was used in the acquisition. Topographic control was done with total station. 


\section{Results}

Fig. 1 depicts the radargram obtained before the water injection, whereas Fig. 2 depicts the first profile after the end of the water injection. All of the 18 GPR sections obtained after the injection were roughly similar to each other. In order to verify differences among them, we proceeded the subtraction of such profiles. With this approach, we were able to identify specificities of the subsurface saturation. The subtractions are represented in Figs. 4 and 5 (radargram 5 minus radargram 1 and radargram 13 minus radargram 1 , respectively).

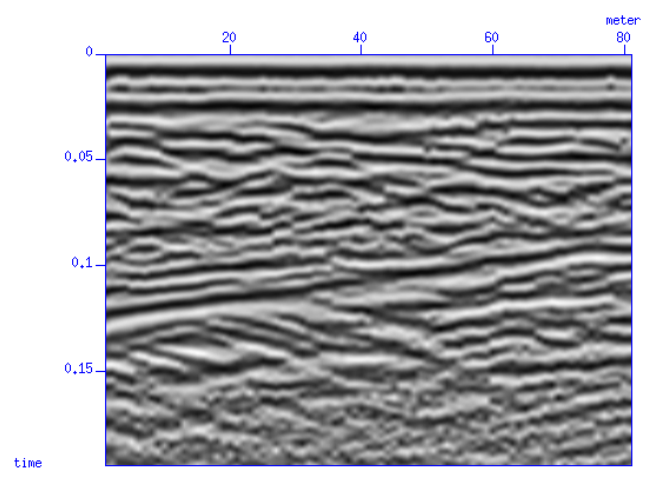

Figure 2 - Radargram obtained before the water injection (background).

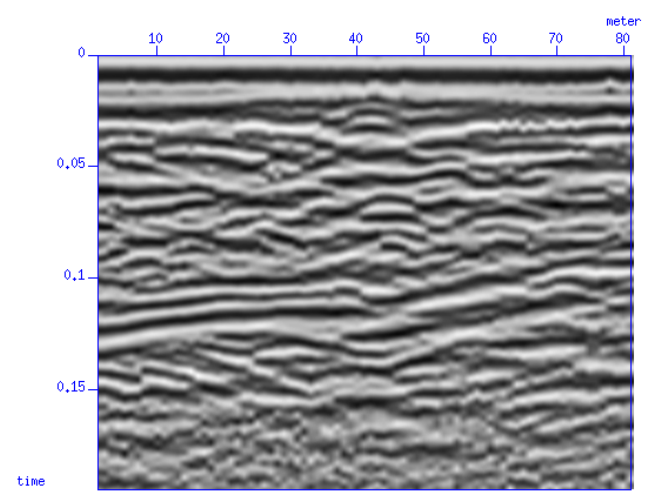

Figure 3 - First radargram obtained after the water injection (radargram 1).

The differences between the the radargram 1 and the subsequent ones (of which Figs. 4 and 5 are examples) allowed us to observe a vertical variation under the injection point, halfway of the profile length, where there exists accumulation of water, characterizing the effect of pull down, which means that the reception of the eletromagnetic waves took a longer time due to the influence of the water injection which caused saturation in this region of the subsurface.

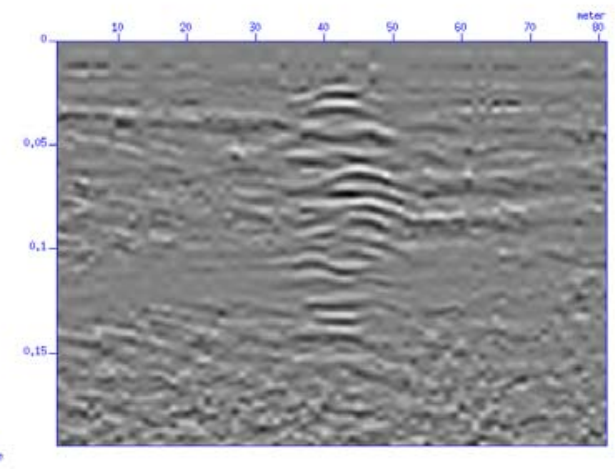

Figure 4 - Subtraction of the profiles correspondent to the radargram 5 and radargram 1 (Fig. 3).

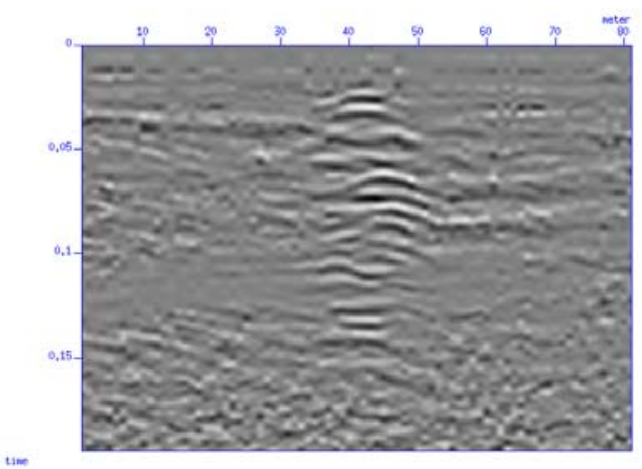

Figure 5 - Subtraction of the profiles correspondent to the radargram 13 and radargram 1 (Fig. 3).

\section{Discussion and Conclusions}

The variation zones found in the middle of the sections of difference (Figs. 4 and 5) present a pattern of reflections under the pull down, beyond the groundwater level, situated approximately $0.03 \mathrm{~ns}$ in the profiles.

Since it is a saturated water zone, we believe that such reflectors exist possibly due to reverberations. Future work encompasses the investigation of the reasons of such phenomenon during GPR surveys in saturated subsurface using modeling softwares.

\section{Acknowledgements}

The authors T.P.R. and J.M.T. are supported by CNPq/Brazilian Ministry of Science and Technology. The author A.A.M.M. is supported by the Brazilian Ministry of Science and Technology. The author T.P.R. acknowledges the researcher Luís Peche Puertas for the discussions during the development of the work. 


\section{Referências}

Davis, J. L., Annan, A.P., 1989. Ground penetrating radar for high resolution mapping of soil and rock stratigraphy. Geophysical Prospecting, 37: 351-551.

Galagedara, L. W., Parkin, G. W., Redman, J. D., Bertoldi, P. von, Endres, A. L., 2005. Field studies of the GPR ground wave method for estimating soil water content during irrigation and drainage.

Huisman, J. A., Hubbard, S. S., Redman, J. D., Annan, A. P., 2003. Measuring Soil Water Content with Ground Penetrating Radar: A Review. Vadose Zone Journal, 2: 476-491. 